\title{
Trends and Seasonal Variation in Prices of Soybean in Major Markets of Maharashtra State, India
}

\author{
S. S. Walke ${ }^{1 *}$, Chowa Ram Sahu ${ }^{2}$, R. M. Takale ${ }^{1}$ and A. R. Kale ${ }^{1}$ \\ ${ }^{1}$ College of Agricultural Allied Sciences, Sharadanagar, Baramati- 413102 (M.S), India \\ ${ }^{2}$ Department of Agricultural Statistics \& Social Science (L.) \\ IGKV, Raipur-492012 (C.G), India \\ *Corresponding author
}

A B S T R A C T

Keywords

Modal prices, Price movements, Secular trends, Seasonal variation

Article Info

Accepted:

23 April 2020

Available Online:

10 May 2020
Soybean is the leading oilseed produced globally. It play significant role in total oilseed production of India. Maharashtra is the second largest producer of soybean after Madhya Pradesh in India. The present study aimed to study price movement of soybean i.e. Secular trend and seasonal variation, among the major soybean markets in Maharashtra. For study purpose the data related to monthly modal prices of soybean were collected from major markets from different markets in States viz. Latur, Khamgaon, Nagpur and Higanghat for the period 2001-02 to 2019-20. There were an increasing trend in the prices of selected soybean markets and was found to be statistically significant at 1 per cent level of significance. The seasonal indices of soybean prices were highest in the month of May and lowest in the month of October during the period of study in the selected soybean markets.

\section{Introduction}

Soybean (Glycine max L.) is known as 'golden bean' and grown all over world for dual purpose that is oil seed as well as pulse crop. The crop also has a prominent place as the world's most important seed legume, which contributes 25 per cent to the global vegetable oil production, about two thirds of the world's protein concentrate for livestock feeding and is a valuable ingredient in formulated feeds for poultry and fish. About 85 per cent of the world's soybean is processed annually into soybean meal and oil.

The major soybean producing nations are the United States, Brazil and Argentina. The three countries dominate global production, 
accounting for 80 per cent of the world's soybean supply. Global production of soybean has grown at a CAGR of 4.1 per cent from 282.749 million metric tons in 2013-14 to 346.919 million metric tons in 2017-18.

Production of soybean in India is dominated by Madhya Pradesh and Maharashtra states which contribute to 89 per cent of the total soybean production in the country. Rajasthan, Telangana, Karnataka, Chhattisgarh and Gujarat states contribute the remaining 11 per cent of production. Maharashtra state the potential of becoming the leader in soybean. It is a kharif crop, cultivated in month of June to July and harvested by September to November. There is a need to have a thorough understanding of trends and seasonal variation in the prices of soybean over time and space as such an analysis is also useful to farmers in order to decide the optimum time for disposing off their produce to their best advantage.

\section{Materials and Methods}

To study the price behavior in the selected markets, the secondary data on monthly modal prices Rs/q) of soybean were collected from the website of Directorate of Marketing \& Inspection (DMI) ,Ministry of Agriculture and Farmers Welfare, Government of India (https://agmarknet.gov.in/) for the period of 16 years from 2001-02 to 2019-20 for Latur, Khamgaon, Hinganghat and Nagpur markets.

\section{Analysis of long-term movements (trend)}

For estimating the long run trend of prices, the method of least squares estimate was employed. This method of ascertaining the trend in a series of annual prices involves estimating coefficient of intercept (a) and slope (b) in the linear function form. The equation adopted for this purpose was specified as follows:

$$
Y_{t}=a+b x+e
$$

$$
\begin{aligned}
& \mathrm{Y}_{\mathrm{t}}=\text { Trend values at time ' } \mathrm{t} ' \\
& \mathrm{X}=\text { Period } \\
& \mathrm{a}=\text { Intercept parameter } \\
& \mathrm{b}=\text { Slope parameter } \\
& \mathrm{e}=\text { Error }
\end{aligned}
$$

Annual trends of prices for the selected markets were computed and compared. The goodness of fit of trend line to the data was tested by the coefficient of multiple determination which is denoted by $\mathrm{R}^{2}$.

\section{Estimation of seasonal indices of monthly data}

The seasonal pattern in prices of soybean was analysed by constructing seasonal index numbers. Seasonal index numbers are set of numbers showing relative prices during different months of a year, the year being 100 and total 1200. In the present study twelve months moving average method was used to measure the seasonal variation in prices, as it is a fairly good estimate of the trend and cyclical components combined.

The steps involved in the construction of seasonal index by this method are:

(i) Generating a series of 12 months moving totals.

(ii) Generating a series of 12 months moving averages.

(iii)Generating a series of centered 12 months moving averages.

(iv)Expressing each original value as a percentage of corresponding centered moving average.

(v) Arranging the percentages of moving averages in the form of monthly arrays and calculating the average index for each month.

(vi)Adjusting the averages to make their sum equal to 1200 . 
This was done by working out the correction factor and multiplying the average for the month by correction factor, which was estimated as follows:

Correction factor $=\frac{1200}{4}$

\section{Results and Discussion}

Trends in prices of soybean selected markets

The trends are the changes over years and are associated with changes in technology of production, input supply, infrastructure etc. The study of trends enables us to indicate the general direction of prices in different markets. For estimating long-run movements of soybean prices in the selected markets, the data relating to prices of soybean were subjected to linear trend analysis.

It is inferred from Table 1 that, the monthly increase in prices of soybean was found to be the highest in Latur market (Rs 14.49/qtl) whereas it was the lowest in Higanghat market (Rs 12.85/qtl). In all these markets, the contribution of independent variable, time to the change in prices was to the tune of 73 per cent to 77 per cent as indicated by $\mathrm{R}^{2}$. There was not much variation in the extent of increase in prices of soybean in the selected markets. But Higanghat market registered the lowest increasing trend compared to other markets under study. However, the trend analysis of prices indicated a positive trend in all the markets.

Table.1 Trends in the prices of soybean in the selected markets

\begin{tabular}{|c|c|c|}
\hline Markets & Equation & $\mathbf{R}^{2}$ \\
\hline Latur & $\mathrm{Y}=818.02^{* *}+14.492^{* *} \mathrm{t}(0.60)$ & 0.74 \\
\hline Khamgaon & $\mathrm{Y}=804.98^{* *}+13.448^{* *} \mathrm{t}(0.58)$ & 0.73 \\
\hline Nagpur & $\mathrm{Y}=826.72^{* *}+13.445^{* *} \mathrm{t}(0.52)$ & 0.77 \\
\hline Hinganghat & $\mathrm{Y}=858.13^{* *}+12.85^{* *} \mathrm{t}(0.49)$ & 0.77 \\
\hline
\end{tabular}

** Significant at $1 \%$ level Figures in parentheses are Standard Errors

Table.2 Seasonal indices of soybean prices in selected markets

\begin{tabular}{|c|c|c|c|c|}
\hline Markets & Latur & Khamgaon & Nagpur & Hinganghat \\
\hline Months & & & & \\
\hline January & 97.71 & 97.76 & 97.33 & 96.65 \\
\hline Mebruary & 98.93 & 99.67 & 98.41 & 98.10 \\
\hline Aprch & 100.87 & 100.59 & 101.59 & 100.08 \\
\hline May & 105.99 & 103.23 & 105.17 & 102.19 \\
\hline June & 109.99 & 108.63 & 108.46 & 106.22 \\
\hline July & 104.77 & 106.72 & 104.47 & 106.32 \\
\hline August & 104.17 & 105.50 & 105.26 & 105.78 \\
\hline September & 99.69 & 104.11 & 105.63 & 102.90 \\
\hline October & 84.89 & 96.06 & 95.62 & 99.13 \\
\hline November & 93.81 & 94.34 & 88.44 & 92.01 \\
\hline December & 95.25 & 93.71 & 94.39 & 95.81 \\
\hline Total & $\mathbf{1 2 0 0}$ & $\mathbf{1 2 0 0}$ & $\mathbf{1 2 0 0}$ & $\mathbf{1 2 0 0}$ \\
\hline
\end{tabular}


Seasonal indices of soybean prices in selected markets

Seasonal fluctuations are the changes that occur regularly every year during the same period. The seasonal changes are caused mainly by the seasonal nature of production of the crop. The seasonal indices of price would show the extent of fluctuations from month to month and can be helpful in indicating the right time for sale of produce.

It is inferred from Table 2 that in the Latur market the highest seasonal index was found in May, followed by April and June as the indices stood at 109.99, 105.99 and 104.77 respectively. Lowest seasonal index was recorded in October with 84.89. Kadam (2016) also observed highest seasonal indices of soybean price in June (108.99) and lowest in the month of October (84.62) in Latur market during the period from 2005-06 to 2014-15. In Khamgaon market highest seasonal index was found in May, followed by June and July as the indices stood at 108.46, 106.72 and 105.50 respectively. Minimum seasonal index was recorded in October with 89.69.

Nagpur market witnessed highest seasonal index in May, followed by August and July as the indices stood at 108.48, 105.63 and 105.26 respectively. Lowest seasonal index was recorded in October with 88.44. In Higanghat market highest seasonal index was found in June, followed by May and July as the indices stood at 106.32, 106.22 and 105.78 respectively. Lowest seasonal index was recorded in October with 92.01. In all the markets the seasonal indices were lowest in the month of October.

The prices of soybean have been shown continuous increasing trend during study period. It is found that, there is seasonality existing in prices of soybean within the year. The seasonal indices were highest in the month of May and lowest in the month of October during the period of study. Such research on prices of agricultural commodities and market information is most important as it helps the farmers in making wise decisions on the crop to be grown, also prevent the farmers exploitation by the middle men and guide the farmers in selling, buying and storage of produce.

\section{References}

Devendra Kumar Verma, Latika Sharma, Hari Singh and Jitendra Suman. 2017 A Study on Price Behaviour of Soybean in Southern Rajasthan. Economic Affairs. $62(3): 531-535$

Kadam, S.K. 2016. Behaviour of arrivals and prices of soybean in Latur regulated market in Maharashtra. International Journal of Multifaceted and Multilingual Studies. 4(12): 1-4

Lakshmi Ramya, S.B., Devi Bhavani, I and Prasad, S.V. 2018. Arrival pattern and trends of chillies (Dry) in Guntur market of Andhra Pradesh. Indian Journal of Agricultural Marketing. 32(1): 63-69.

\section{How to cite this article:}

Walke, S. S., Chowa Ram Sahu, R. M. Takale and Kale, A. R. 2020. Trends and Seasonal Variation in Prices of Soybean in Major Markets of Maharashtra State, India. Int.J.Curr.Microbiol.App.Sci. 9(05): 2912-2915. doi: https://doi.org/10.20546/ijcmas.2020.905.344 